\title{
INDICATORI AI ECONOMIEI ȘI SOCIETĂȚII DIGITALE ÎN ROMÂNIA ȘI UE-28 ÎN CONTEXTUL REALITǍŢILOR ȘI PERSPECTIVELOR DEMOGRAFICE
}

\author{
Alina-Georgeta AILINCĂ ${ }^{\oplus}$, dr., CSIII, \\ Centrul Cercetări Financiare și Monetare "Victor Slăvescu", \\ Institutului Național de Cercetări Economice „Costin C. Kirițescu” al Academiei Române \\ DOI: https://doi.org/10.36004/nier.cdr.2019.14-08 \\ JEL Classification: J11, L86, O33, O52.
}

Atât în presă cât și în mediu economic se vorbește adesea de realitățile și provocările economiei digitale, dar aceste aspecte ar trebui analizate nu numai individual, ci și integrat. Creșterea economică nu mai poate fi separată de progresul tehnologic și de pătrunderea adâncă a economiei digitale în viața de zi cu zi, afacerile se bazează pe conexiunile rapide la internet, iar tehnologia reprezintă din ce în ce mai mult un punct central al vieții fiecărui cetățean, cuplând mai uşor nevoile individului cu satisfacerea lor prin conectarea mai facilă și mai ieftină cu ofertele companiilor. Astfel, prin apelarea la statisticile și indicatorii Eurostat, acest articol încearcă să releve avantajele și dezavantajele economiei digitale, comparativ în România și la nivelul mediei UE28 prin raportarea la evoluțiile demografice, punctând eventualele soluții de compensare a neajunsurilor sociale din cele două areale.

Cuvinte-cheie: economie digitală, indicatori DESI, România, provocări demografice.

Both in the media and in the economic environment are often spoken of about the realities and challenges of the digital economy, but these issues should be considered not only individually but also integrated. Economic growth can no longer be separated from technological progress and the deep penetration of the digital economy into everyday life, business is based on fast internet connections and technology is increasingly a central point in every citizen's life, connecting the needs of the individual more easily with their satisfaction by making it easier and cheaper to connect with companies' offers. Thus, by using Eurostat statistics and indicators, this article tries to reveal the advantages and disadvantages of the digital economy, comparatively in Romania and EU-28, by reference to demographic developments, pointing out possible solutions to compensate the social shortcomings in the two areas.

Key words: digital economy, DESI indicators, Romania, demographic challenges.

\section{Introduction}

In order to keep up with the most developed countries of the world, the European Commission designed a composite, overall index -Digital Economy and Society Index (DESI), which reveal by its 30 relevant indicators the digital performance at European level. DESI quantifies the development level of technologies of EU member states by containing twelve subdimensions and five dimensions:1. Connectivity, 2. Human Capital, 3. Use of Internet, 4. Integration of Digital Technology and 5. Digital Public Services.

The index captures better the performance when it is higher (Russo, 2019)[4]. The domain are normalised with weights such as: domain 1 with $25 \%$, domain 2 with $25 \%$, domain 3 with $15 \%$, domain 4 with 20\%, domain 5 with 15\%. The first two domains (Connectivity and Human Capital) are considered the most relevant dimensions, representing the infrastructure of the digital economy. The Use of Internet (by citizens) and Digital Public Services, being based on the quality of the infrastructure, they were weighed less, and the Integration of Digital Technology, which surprise the business sector use of ICT is weighted a little bit more.

\footnotetext{
๑ Alina-Georgeta Ailincă, alina.glod@gmail.com
} 
In 2019, the digital performance of all EU countries improved according to the DESI, thus Finland, Sweden and the Netherlands scored the highest ratings, while the poorest scores were registered by Greece, Romania and Bulgaria. It should not be neglected that the ranking somehow reflects the geographical positioning of the countries, the Nordic countries with a less favourable climate for physical activities have good scores at DESI, and the Mediterranean and Eastern countries have rather poorer scores. According to the Unguru M. (2017)[5] the DESI components suggests that Romania is in a vicious circle of digital skills, where both the demand and the supply are low, despite of numerous ICT specialists and good connectivity. Thus, the author considers that it is likely that digitization will further deepen Romania's competitiveness gap with the European Union states. However, the digitalisation of the Romanian economy has lagged behind on the grounds of the fact that less than one third of the population have basic digital skills and more than one fifth of Romanians have never used the internet (European Comission, 2019)[2]. The DESI indicators of Romania may have many reasonable explanations also in social, cultural and especially demographic trends.

\section{Methodology}

The article proposes a stage evaluation by comparative method between the DESI index for Romania respectively for EU28, as well as of its components. Equally, it intends to connect the evolution of DESI with a series of demographic indicators in order to be able to anchor in the explanations the less favourable evolution of DESI in Romania. The data used are the annual series of Eurostat and European Commission for the period 2014-2019.

\section{Results}

Although with a progressive evolution, the Digital Economy and Society Index (DESI) in Romania has still a long way to go to improve all of its five dimensions (see Fig. 1.).

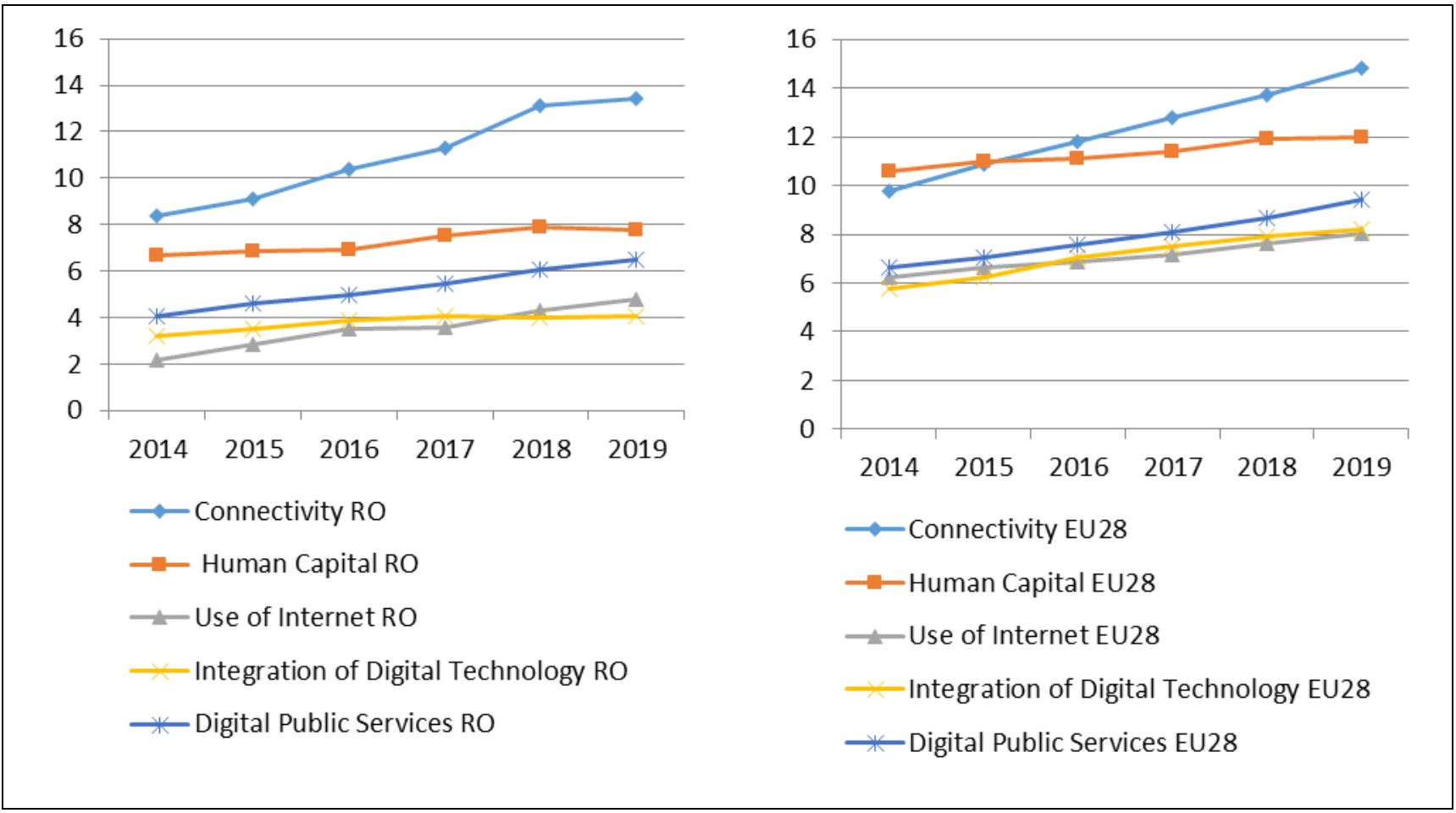

Figura 1. The evolution of the five dimensions Digital Economy and Society Index in Romania and EU28

Source: Author's processing, data from European Commission (Digital Economy and Society Index), all the five dimensions are expressed as weighted scores, \%. https://digital-agenda-data.eu/datasets/desi/indicators [1]. 
The poor scores of the five indicators of DESI in Romania may reflect to some extent certain psychological (being an ex-communist country), cultural (by preference for direct communication), social (lack of access to basic conditions, especially of rural population, thus the internet technology being in many households still a luxury) but not least demographic realities. The departure of a considerable number of Romanians abroad over the last 30 years has led to a massive depopulation in the urban but especially rural areas, which can be a good explanation for many unfavourable macroeconomic indicators including DESI (see Fig. 2., Fig. 3., Fig. 4.).

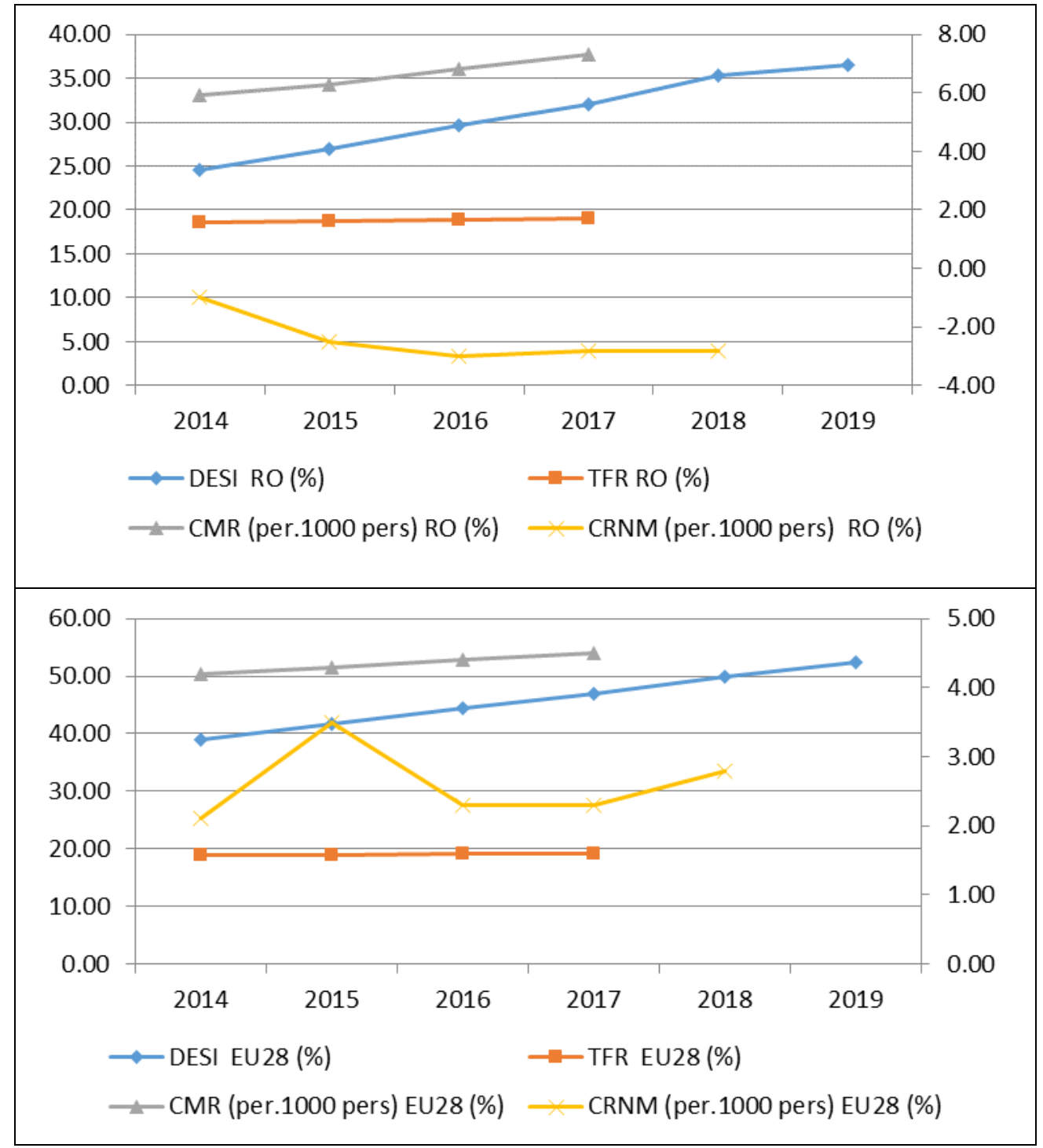

Figura 2. The evolution of Digital Economy and Society Index and of Total fertility rate, Crude marriage rate and Crude rate of net migration plus statistical adjustment in Romania and EU28

Source: Author's processing, data from Eurostat and European Commission, https://digital-agendadata.eu/datasets/desi/indicators. Notations: DESI (\%) - overall Digital Economy and Society Index, weighted score; TFR (\%) - Total fertility rate (\%); CMR (per.1000 pers.) (\%) - Crude marriage rate (Per 1000 persons); CRNM (per.1000 pers.) (\%) - Crude rate of net migration plus statistical adjustment, RO - Romania; EU28 - European Union with 28 countries. TFR, CMR, CRNM - right axis.

The positive correlations between DESI and demographic trends such as of the crude marriage rate and to a much lesser extent to total fertility rate reflects the fact that young people social status has an important say in the evolution of digital economy. This still unsatisfactory 
condition of the economy is quite well reflected by the Crude rate of net migration plus statistical adjustment, which for Romania unfortunately continues to deteriorate even further.

Even it is affected by negative net migration, the DESI overall index in Romania seems to go on a steady upward trend. The improvement of labour force participation it is recognised to have more impact on coping with population aging than fertility or migration. Improving education is thus a key way for the future of world population growth, especially by the fact that a smaller but more educated labour force may be more adaptable to the automation, artificial intelligence or others changing nature of work. Neither more immigration (which increases the size of EU's labour force) nor higher fertility will stop or delay population ageing. This can be solved by the flexible retirement ages and more productive lives (Lutz W.(ed.) and al., 2019[3]).

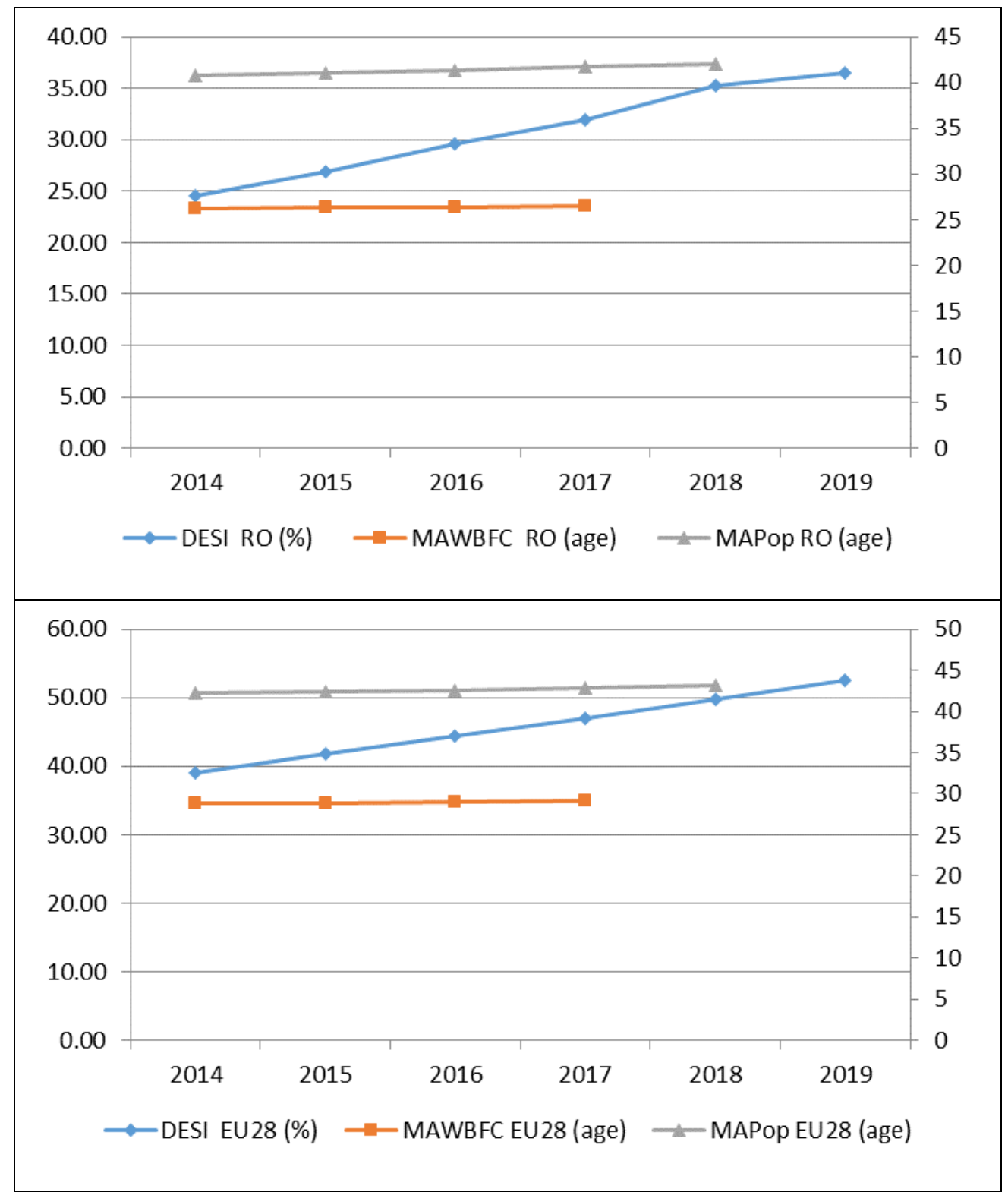

Figura 3. The evolution of Digital Economy and Society Index, of Mean age of women at birth of first child and of Median age of population in Romania and EU28

Source: Author's processing, data from Eurostat and European Commission, https://digital-agendadata.eu/datasets/desi/indicators. Notations: DESI (\%) - overall Digital Economy and Society Index, weighted score; MAWBFC (age) - Mean age of women at birth of first child; MAPop (age) - Median age of population; RO - Romania; EU28 - European Union with 28 countries. MAWBFC, MAPop - right axis. 
Thus the working force migration from the East EU member states towards the West, towards more prosperous countries contributes also to aging and population reduction, but aging is much more visible at EU countries. Respecting the proportions, even if the images are approximately identical between Romania and the EU28 average (see Fig. 3.), however when it comes to Mean age of women at birth of first child and Median age of population the situation is much more negative at EU28 level. A younger population and younger mothers in Romania compared to the EU28 may mean greater and faster possibilities for improving DESI, even the population is decreasing (see Fig. 4.).

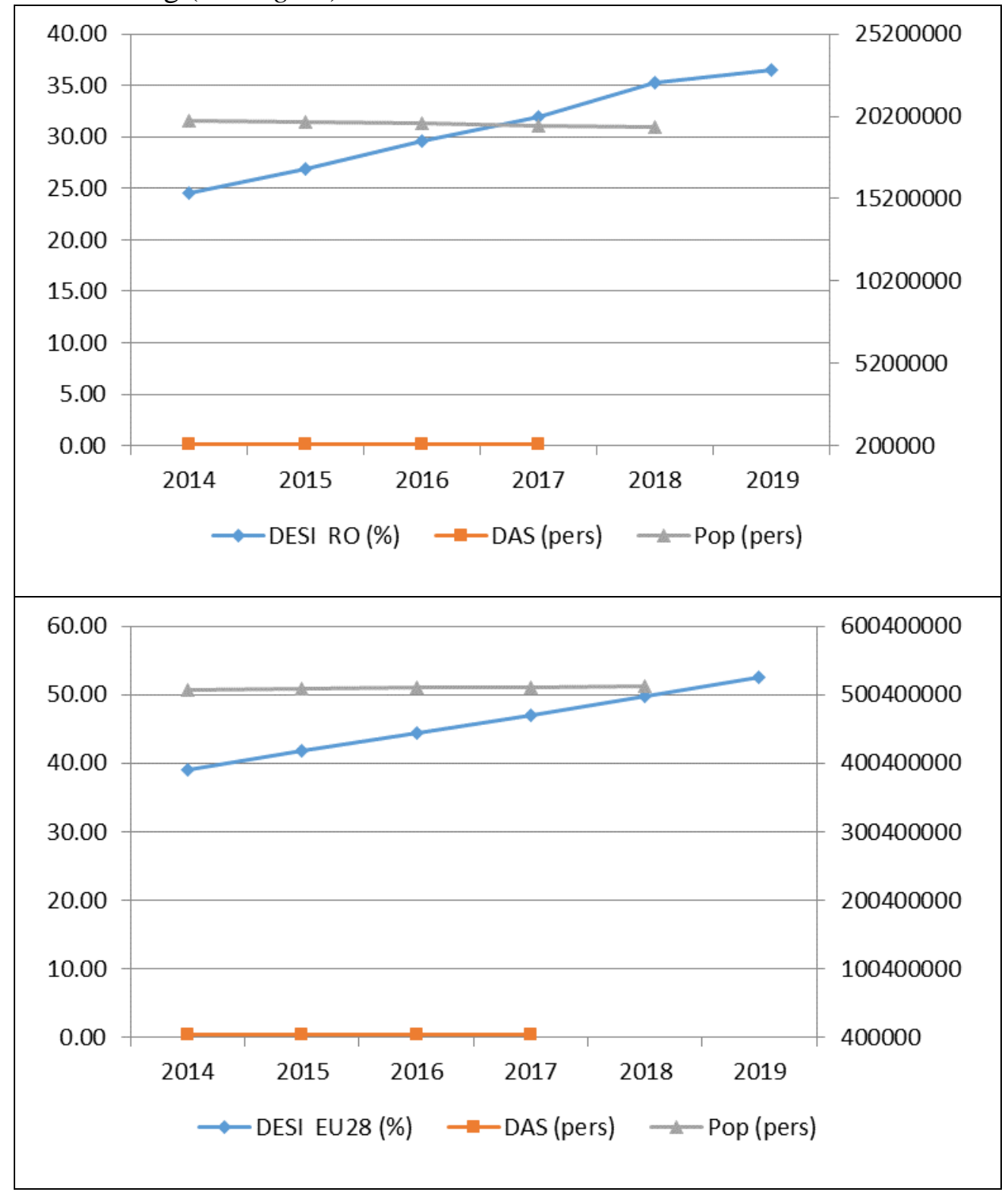

Figura 4. The evolution of Digital Economy and Society Index, of Deaths by age and sex and of Population on 1 January by age and sex in Romania and EU28

Source: Author's processing, data from Eurostat and European Commission, https://digital-agendadata.eu/datasets/desi/indicators. Notations: DESI (\%) - overall Digital Economy and Society Index, weighted score; DAS (pers.) - Deaths by age and sex; Pop (pers.) - Population on 1 January by age and sex; RO - Romania; EU28 European Union with 28 countries. DAS, Pop - right axis.

Media, economists - theorists and practitioners, public policymakers should better understand demographic trends and further promote training policies and professionalization of the workforce. The computerization and technologicalization of the world's economies can be an 
extraordinary social and cultural lever capable of partially compensating for the negative demographic trends.

Promoting peace and not violence, attracting the best specialists in any field, generous public investments in all that means human capital (including those indicators from DESI), respect and trust between citizens and public institutions can make the difference between a developed society and one unable to touch its potential.

\section{Conclusions}

For the Eastern European Countries such as Romania, nothing can stop the intra-EU mobility and the "brain drains" of the youngest and more determined persons. The lack of economic and social opportunities, few appropriate jobs, the failure to comply with the rules of democracy, the corruption, the intentional capping and blocking of the people that are the "peaks" of society, all of them led to the migration of the young and working population from Romania to abroad. The reversal of these causes can therefore lead to the reversal of the negative demographic effects and also will conduct to DESI improvement.

In order to compensate the trends in ageing population of Romania, the immigrations and the increase of fertility rates through well orchestrated policies might be temporary (e.g. through working permits or by attracting highly educated and highly-skilled people) or medium term solutions but the most important development "vehicle" could be education, including in digitalisation.

Although it is negatively influenced by the demographic developments in Romania, the process of digitalisation increases. This fact reflected by the evolution of Digital Economy and Society Index (DESI). This tendency is reflected fortunately rather by the qualitative aspects of the Romanian demographic evolutions, than by the quantitative ones.

The subject deserves much more attention, and as the time series will increase for Romania, an econometric analysis would be of interest in order to better understand and evaluate the connection between the DESI components and the main demographic indicators.

\section{Bibliography}

1. European Commission, Digital Single market, Digital Scoreboarg, Visualizations, Digital Economy and Society Index (DESI). https://digital-agenda-data.eu/datasets/desi/indicators.

2. European Comission, Indicele economiei și societăţii digitale (DESI) Raportul de țară din 2019 România. https://ec.europa.eu/info/sites/info/files/file_import/2019-european-semestercountry-report-romania_ro.pdf.

3. Lutz W. (Ed.), Amran G., Bélanger A., Conte A., Gailey N., Ghio D., Grapsa E., Jensen K., Loichinger E., Marois G., Muttarak R., Potančoková M., Sabourin P., Stonawski M. Demographic Scenarios for the EU - Migration, Population and Education, 2019, EUR 29739 EN, Publications Office, Luxembourg. DOI:10.2760/590301, JRC116398.

4. Russo Vanessa. Digital Economy and Society Index (DESI) European Guidelines and empirical Applications on the Territory. In: Sánchez-Serrano, José Luis Sarasola, Maturo, Fabrizio and Hošková-Mayerová, Šárka (editors). Qualitative and Quantitative Models in Socio-Economic Systems and Social Work. Studies in Systems, Decision and Control 208, Springer, 2019. ISSN 2198-4190 (electronic), ISBN 978-3-030-18593-0 (eBook).

5. Unguru M. Decalajele digitale în UE şi perspectivele economiei informaţionale în România. EUROINFO, 2017, 1(11-12), p. 87-95. 